\title{
EFFECT OF SPATIAL-TEMPORAL VARIATION OF LAND USE AND LAND COVER ON SOIL EROSION ${ }^{1}$
}

\author{
GUILHERME HENRIQUE EXPEDITO LENSE ${ }^{2}$, TAYA CRISTO PARREIRAS ${ }^{2}$, RODRIGO SANTOS MOREIRA ${ }^{2}$, \\ JUNIOR CESAR AVANZI ${ }^{3}$, RONALDO LUIZ MINCATO ${ }^{4}$
}

\begin{abstract}
Land use and land cover changes are the main factors of human influence on the erosive process. Thus, this work aimed to evaluate the effect of land use and land cover changes over 30 years on water erosion in a tropical subbasin in southeastern Brazil. The hypothesis was tested that the expansion of coffee and reforestation areas decreased soil losses due to water erosion. The Potential Erosion Method (EPM) was used to estimate water erosion in 1988, 1998, 2008 and 2018. In the first two decades, the predominant land use in the subbasin was corn, while in 2008 and 2018, coffee and reforestation areas became the main land use class in the area. The acquisition of EPM input parameters and data analysis was performed using remote sensing techniques and the Geographic Information System. Between 1988 and 1998, the total soil loss increased by $50.36 \mathrm{Mg}$ year $^{-1}$ due to the conversion of pasturelands to coffee plantations and the increase of deforestation. However, between 1998 and 2018, there was a soil loss reduction of $660.21 \mathrm{Mg}$ year ${ }^{-1}(-37.46 \%)$, once the conversion of pasture and corn areas to coffee with the adoption of conservation practices, and the expansion of reforestation areas among 1988 - 2018, contributed to the decrease of soil erosion rates.
\end{abstract}

Keywords: Soil conservation. Modelling. Erosion Potential Method.

\section{EFEITO DA VARIAÇÃO ESPAÇO-TEMPORAL DO USO E COBERTURA DA TERRA SOB A EROSÃO DO SOLO}

\begin{abstract}
RESUMO - As mudanças no uso e cobertura da terra são os principais fatores de influência humana no processo erosivo. Dessa forma, o trabalho teve como objetivo avaliar o efeito das mudanças de uso e cobertura da terra ao longo de 30 anos sob a erosão hídrica em uma sub-bacia tropical no sudeste do Brasil. Foi testada a hipótese de que a expansão das áreas de café e reflorestamento diminuíram as perdas de solo por erosão hídrica. Utilizou-se o Método de Erosão Potencial (EPM) para estimar a erosão hídrica em 1988, 1998, 2008 e 2018. Nas duas primeiras décadas, o uso da terra predominante na sub-bacia era o milho, enquanto em 2008 e 2018 , o café e as áreas de reflorestamento se tornaram as principais classe de uso da terra da área. A aquisição dos parâmetros de entrada do EPM e a análise dos dados foi realizada por meio de técnicas de sensoriamento remoto e Sistema de Informações Geográficas. Entre 1988 e 1998, a perda total de solo aumentou $50,36 \mathrm{Mg}$ ano $^{-1}$ devido à conversão de pastagens em plantações de café e o aumento do desmatamento. Entre 1998 e 2018, houve uma redução nas perdas de solo de 660,21 Mg ano ${ }^{-1}(-37,46 \%)$. A conversão de áreas de pastagem e milho em cultivos de café com adoção de práticas conservacionistas e a expansão de áreas de reflorestamento entre 1988-2018 contribuíram para a diminuição das taxas de erosão do solo.
\end{abstract}

Palavras-chave: Conservação do solo. Modelagem. Método de Erosão Potencial.

\footnotetext{
${ }^{*}$ Corresponding author

${ }^{1}$ Received for publication in 02/07/2020; accepted in 09/24/2020.

${ }^{2}$ Graduate Program in Environmental Sciences, Universidade Federal de Alfenas, Alfenas, MG, Brazil; guilherme.lense@sou.unifalmg.edu.br - ORCID: 0000-0002-3560-9241, tayacristo1@gmail.com - ORCID: 0000-0003-2621-7745, rodrigosagro@yahoo.com.br ORCID: 0000-0001-7443-9428.

${ }^{3}$ Department of Soil Science, Universidade Federal de Lavras, Lavras, MG, Brazil; junior.avanzi@ufla.br - ORCID: 0000-0003-24550325 .

${ }^{4}$ Institute of Natural Sciences, Universidade Federal de Alfenas, Alfenas, MG, Brazil; ronaldo.mincato@unifal-mg.edu.br - ORCID: 00000001-8127-0325.
} 


\section{INTRODUCTION}

Water erosion is the main form of land degradation worldwide, and it can compromise food, fiber, and energy production, as well as the maintenance of other soil ecosystem services (FAO, 2017). The erosion process affects both the sediment generation area, and deposition site, with physical and socioeconomic impacts, such as reduced agricultural productivity, loss of water storage capacity, nutrient and organic matter removal, and siltation and pollution of watercourses (BESKOW et al., 2009; AVANZI et al., 2013; POSTHUMUS et al., 2015). Land use and land cover are recognized as the main factors of human influence on soil erosion (OUYANG et al., 2010; DEVÁTÝ et al., 2019). The cultivation of new crops without environmental planning decreases soil protection, which increases the runoff process and the erosive intensity.

Brazil have been facing land-use changes with a rapid expansion of some crops since the 1980s, which has also brought changes in the erosion dynamics (MANZATTO; FREITAS JUNIOR; PERES, 2002; DIAS et al., 2016). These changes can be observed in the Coroado Stream subbasin, located in the state of Minas Gerais, southeastern Brazil, which is an ideal place for studies on the relationship between land-use change and water erosion.

In the 1980s, pasture and temporary crops were the predominant land-uses in the subbasin area, as well as most of the southeast region of the country (DIAS et al., 2016). Since 1990, due to government incentives and economic reasons, much of the subbasin was turned into coffee-growing areas (SIMÕES; PELEGRINI, 2010). Moreover, the subbasin experienced a reforestation process to comply with the Brazilian Forest Code (BRASIL, 2012). Thus, significant land-use changes occurred in the area with the replacement of pastures and temporary crops by coffee and reforestation.

Simulation models are an effective way to assess the impacts of land use and land cover changes on soil erosion (VANWALLEGHEM et al., 2017). The use of models with little input data requirements such as Erosion Potential Method (EPM) (GAVRILOVIC, 1962) can support environmental planning in areas exposed to high erosion risks. The EPM is an empirical soil erosion model that takes into account individual subbasin parameters, concerning climate, geological, topographic, and land use and management. Moreover, it is a simple and inexpensive method that can be associated with remote sensing techniques and Geographic Information Systems (GIS) to identify areas of high vulnerability to the erosive process, providing accurate and reliable results (EFTHIMIOU; LYKOUDI; KARAVITIS, 2017).

Although land cultivation generally accelerates the erosion process, understanding the effects of land use and land cover on the spatial and temporal dynamics of erosion, especially in areas under long-term agricultural use, is a critical and necessary issue to identify efficient mitigation measures (DIDONÉ; MINELLA; EVRARD, 2017; OUYANG et al., 2018). Thus, the work aimed to evaluate the effects of the land use and land cover changes over 30 years on water erosion in a tropical subbasin in southeastern Brazil. The hypothesis that the expansion of coffee and reforestation areas decreased the soil losses by water erosion was tested.

\section{MATERIAL AND METHODS}

\section{Description of the study area}

The study was carried out at the Coronado Stream subbasin that belongs to the Rio Grande basin. The area is located at Capoerinha farm, owned by Ipanema Agrícola SA, in Alfenas, Minas Gerais, Brazil, at coordinates illustrated in Figure 1 (Geographic Coordinate System Datum Sirgas 2000). The Slope Map was elaborated in the ArcMap 10.3 environment, applying the Slope tool (ESRI, 2015), using the Digital Elevation Model (DEM), extracted from the Alfenas Topographic Map, with a spatial resolution of $10 \mathrm{~m}$ (IBGE, 1970).

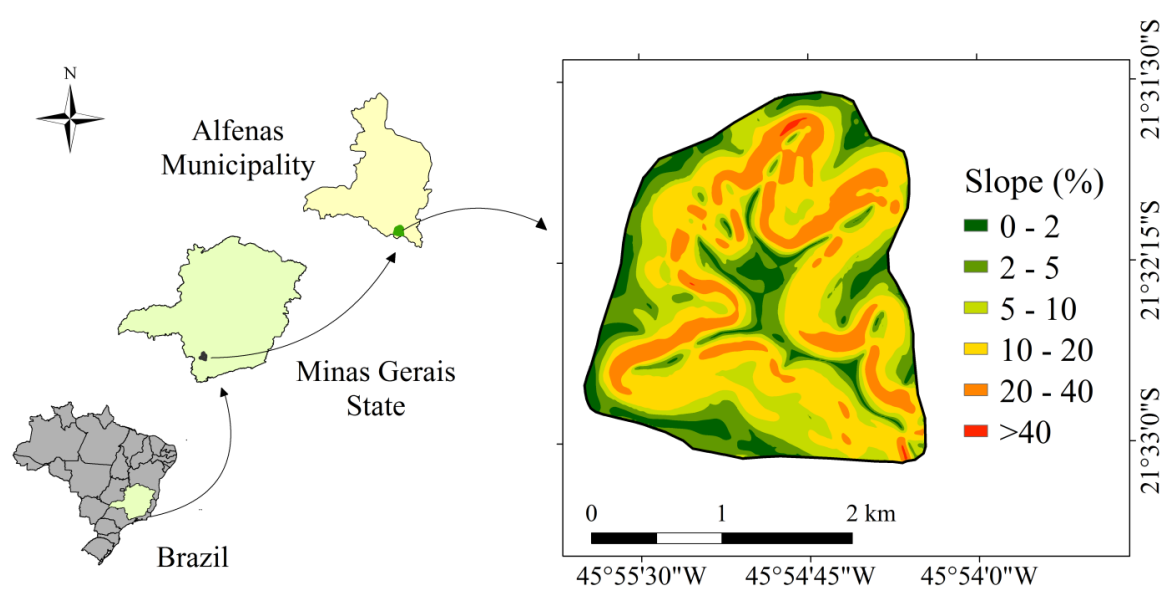

Figure 1. Location and declivity Map of the Coroado Stream Subbasin, Alfenas Municipality, south of Minas Gerais State, Brazil.

Rev. Caatinga, Mossoró, v. 34, n. 1, p. 90 - 98, jan. - mar., 2021 
The climate was classified according to Köppen's classification as Humid subtropical with dry winter and temperate summer (ALVARES et al., 2013), while the soil was sorted as Oxisols (SOIL SURVEY STAFF, 2014). The structure of Oxisols in the subbasin is granular of moderate degree with medium size. The soils in the area have a clayey texture and an average organic matter content of $2.56 \mathrm{dag} \mathrm{kg}^{-1}$ (LENSE et al., 2019).

The land use and occupation map (Figure 2) was generated based on the Capoeirinha farm occupation history and images of the Landsat-5 Thematic Mapper (TM) satellites, bands 1, 2 and 3 and Landsat-8 Operational Land Imager (OLI), bands 2, 3 and 4, both corresponding to orbit/point 219/75, obtained from the Imaging Division (INPE, 2019). The following dates were selected: July 05, 1988; July 07, 1998; July 01, 2008 for Landsat-5 TM, and July 13, 2018 for Landsat-8 OLI, once favorable atmospheric conditions were needed. The image processing was performed using ArcGIS 10.3 (ESRI, 2015), and the land-use classification, built from these images, is shown in Table 1.

The soil loss was estimated by water erosion in 1988, 1998, 2008, and 2018. In the first two decades, the predominant land-use in the subbasin was corn, while in 2008 and 2018, coffee became the majority land use class in the area (Table 1).
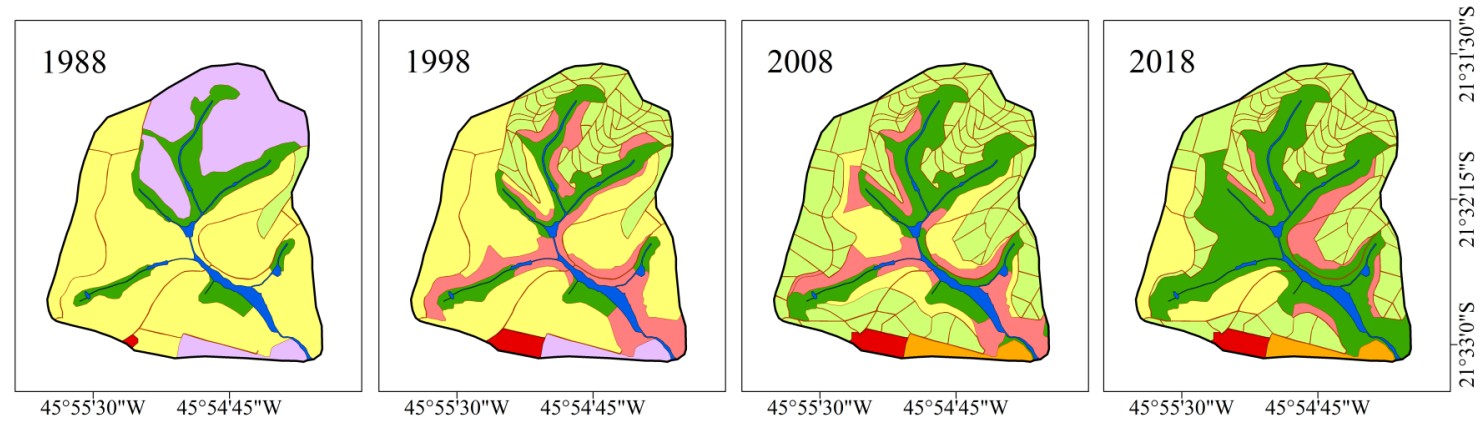

Land Use

$\square$ Coffee $\square$ Eucalyptus

$\square$ Corn $\square$ Forest

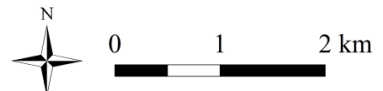

Figure 2. Map of land use classes of the Coroado Stream Subbasin, Alfenas Municipality, south of Minas Gerais State, Brazil, in the years 1988, 1998, 2008 e 2018.

Table 1. Land use classes of the Coroado Stream Subbasin, Alfenas Municipality, south of Minas Gerais State, Brazil, in the years 1988, 1998, 2008 and 2018.

\begin{tabular}{lcccc}
\hline \multirow{2}{*}{ Land Use } & \multicolumn{3}{c}{ Area (\%) } & 2008 \\
\cline { 2 - 5 } & 1988 & 1998 & 0.00 & 2018 \\
\hline Pasture & 22.91 & 2.77 & 45.56 & 0.00 \\
Coffee & 1.66 & 16.78 & 12.49 & 18.32 \\
Corn & 58.21 & 45.50 & 2.70 & 11.70 \\
Forest & 12.98 & 11.90 & 12.37 & 34.66 \\
Sugarcane & 0.00 & 0.00 & 3.66 & 3.11 \\
Eucalyptus & 0.00 & 15.80 & 3.13 & 3.50 \\
Access Roads & 0.91 & 2.41 & 3.13 \\
Drainage & 3.13 & 3.13 & 1.77 \\
Facilities & 0.20 & 1.71 & & 1.77 \\
\hline
\end{tabular}

\section{Erosion Potential Method (EPM)}

The soil losses by the EPM were estimated using the equations described in Table 2.

\section{Determination of parameters without temporal variation}

The area of the subbasin is $5,595 \mathrm{~km}^{2}(\mathrm{~F})$, with an average altitude of $861 \mathrm{~m}$. The perimeter corresponds to $9.28 \mathrm{~km}(\mathrm{O})$, and the extension of the area, measured from the watercourses, is $3.32 \mathrm{~km}$
(L). The average elevation difference (D) was $66 \mathrm{~m}$, obtained from the difference between the average $(861 \mathrm{~m})$ and the minimum altitude $(795 \mathrm{~m})$.

The coefficient of retention $\left(R_{u}\right)$ was quantified based on the parameters $\mathrm{O}, \mathrm{D}$, and L. The $\mathrm{R}_{\mathrm{u}}$ was estimated in 0.118 , indicating that $88.20 \%$ of the total sediments $\left(\mathrm{W}_{\mathrm{yr}}\right)$ generated from the erosion process is retained in the subbasin. Therefore, only $11.80 \%$ represent the real soil loss $\left(\mathrm{G}_{\mathrm{yr}}\right)$, once it is what reaches the water systems. The area has a mean slope $\left(\mathrm{I}_{\mathrm{sr}}\right)$ of $13.54 \%$ (Figure 1) and presents a predominance of rolling relief $(8-20 \%)$. 
Soil resistance to erosion (Y) changes according to the geology and the soil type. The $\mathrm{Y}$ values range from 0.20 (soils with high erosion resistance) to 2.0 (soils with a low erosion resistance). According to Gavrilovic (1962), Oxisols present a $\mathrm{Y}$ value of 0.8 . The EPM results were converted from $\mathrm{m}^{3}$ year $^{-1}$ to $\mathrm{Mg}$ year ${ }^{-1}$ using subbasin soil average density (Ds) of $1.22 \mathrm{~kg} \mathrm{dm}^{-3}$ (LENSE et al., 2019).

Table 2. Equations and descriptions of the parameters used to estimate soil losses in the Erosion Potential Method.

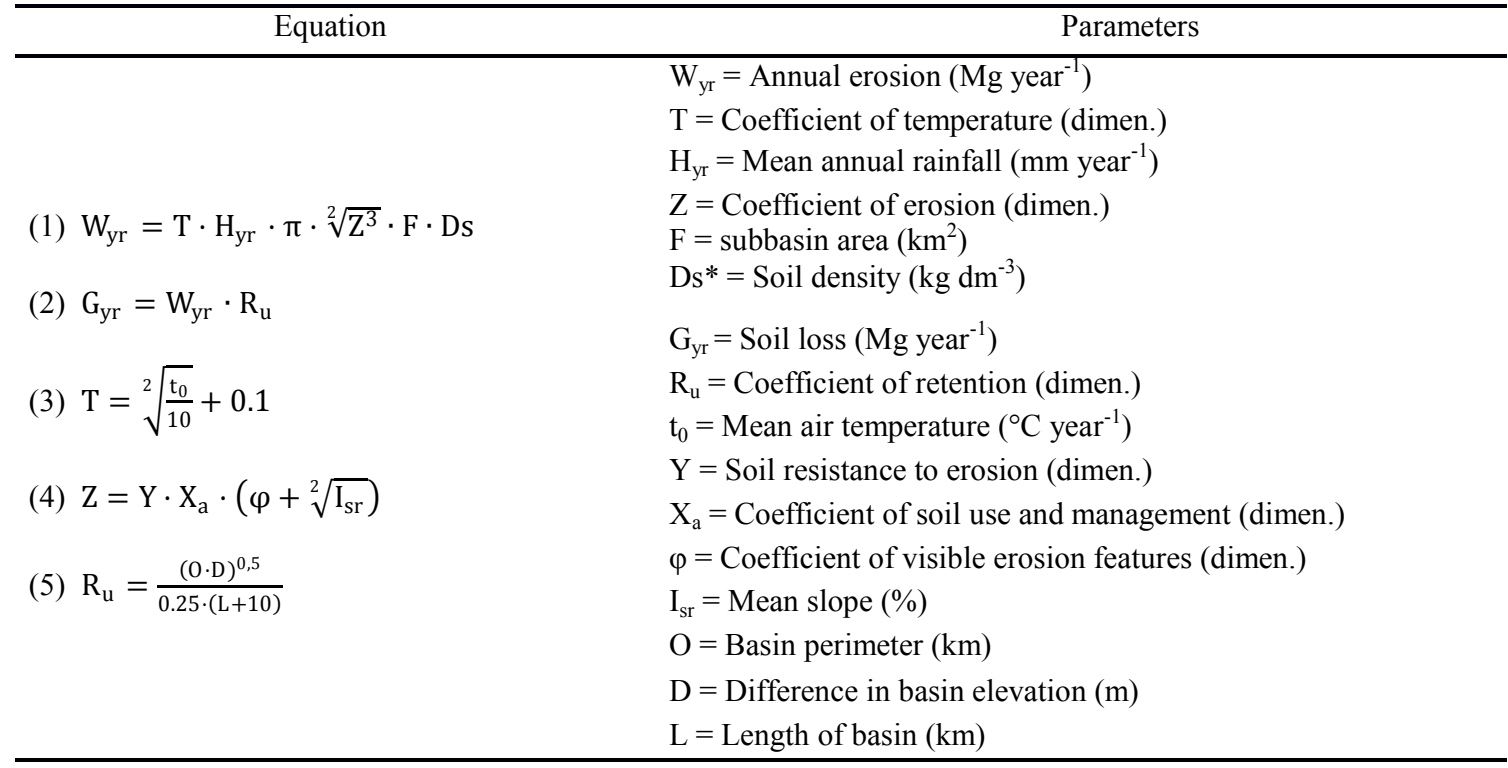

Notes: dimen. $=$ dimensionless. ${ }^{*}$ Parameter incorporated into the original formula for conversion of $\mathrm{m}^{3}$ year $^{-1}$ to $\mathrm{Mg}$ year $^{-1}$. Source: Gavrilovic (1962).

\section{Determination of parameters with temporal variation}

The soil use and management coefficient $\left(\mathrm{X}_{\mathrm{a}}\right)$ expresses the protection of an area against rainfall action, according to the soil cover. The values range from 0.1 (areas with dense vegetation) to 1.0 (areas with exposed soil). The coefficient of visible erosion features $(\varphi)$, ranges from 0.1 (sites without signs of erosion) to 1 (sites with severe erosive featuresgullies). The coefficients $X_{a}$ and $\varphi$ were determined for each year $(1988,1998,2008,2018)$ using the satellite images, and they were classified for each land-use class according to Gavrilovic (1962) (Table 3).

Table 3. Classification of the coefficients: land use and management $\left(X_{a}\right)$ and visible erosion features $(\varphi)$.

\begin{tabular}{lc}
\hline \multicolumn{1}{c}{ Land Use } & $\mathrm{X}_{\mathrm{a}}$ \\
\hline Bare Soil & $0.9-1.0$ \\
Annual cultivation & $0.7-0.9$ \\
Perennial cultivation & $0.5-0.7$ \\
Pasture & $0.3-0.5$ \\
Native Vegetation & $0.1-0.3$ \\
\hline \multicolumn{1}{c}{ Coefficient of visible erosion features } & $\varphi$ \\
\hline Whole subbasin affected by erosion & $0.9-1.0$ \\
50 - 80\% of catchment area affected by surface erosion & $0.8-0.9$ \\
Erosion in rivers, gullies and alluvial deposits & $0.5-0.8$ \\
Erosion in subbasin on 20 - 50\% of the catchment area & $0.3-0.5$ \\
Little erosion on subbasin & $0.1-0.3$ \\
\hline
\end{tabular}

Source: Adapted from Gavrilovic (1962) and Efthimiou, Lykoudi and Karavitis (2017). 
The erosion coefficient $(\mathrm{Z})$ expresses the soil erosion susceptibility in which values close to 0 indicate lower risks. The $\mathrm{Z}$ is determined using $\mathrm{Y}$, $\mathrm{X}_{\mathrm{a}}, \varphi$, and the mean slope of the area $\left(\mathrm{I}_{\mathrm{sr}}\right)$. The annual precipitation $\left(\mathrm{H}_{\mathrm{yr}}\right)$ and the mean air temperature $\left(\mathrm{t}_{0}\right)$ represent the interference of climatic factors in the erosive process, and these parameters were obtained from the "Instituto Nacional de Meteorologia" database (INMET, 2019). The temperature coefficient $(\mathrm{T})$ was determined using $\mathrm{t}_{0}$. The EPM parameters with temporal variation are shown in Table 4.

Table 4. Parameters values of the Erosion Potential Method in the Subbasin, Alfenas Municipality, south of Minas Gerais State, Brazil, in different periods.

\begin{tabular}{lcccc}
\hline \multirow{2}{*}{ Parameters } & \multicolumn{3}{c}{ Year } \\
\cline { 2 - 5 } & 1988 & 1998 & 2008 & 2018 \\
\hline $\mathrm{X}_{\mathrm{a}}$ (dimen.) & 0.58 & 0.60 & 0.54 & 0.45 \\
$\varphi($ dimen.) & 0.57 & 0.57 & 0.48 & 0.40 \\
$\mathrm{Z}($ dimen.) & 0.44 & 0.46 & 0.38 & 0.30 \\
$\mathrm{t}_{0}\left({ }^{\circ}\right.$ year $\left.^{-1}\right)$ & 19.93 & 20.32 & 20.04 & 20.62 \\
$\mathrm{H}_{\text {yr }}\left(\right.$ mm year $\left.^{-1}\right)$ & $1,401.50$ & $1,366.30$ & $1,417.70$ & $1,408.00$ \\
$\mathrm{~T}$ (dimen.) & 1.51 & 1.53 & 1.52 & 1.54 \\
\hline
\end{tabular}

Notes: $X_{a}=$ Average of Coefficient of soil use and management; $\varphi=$ Average of Coefficient of visible erosion features; $Z=$ Average of Coefficient of erosion; $\mathrm{t}_{0}=$ Mean air temperature; $\mathrm{H}_{\mathrm{yr}}=$ Mean annual rainfall; $\mathrm{T}=$ Coefficient of temperature; dimen $=$ dimensionless

The EPM calculations and the spatial distribution of the results were performed at ArcGIS 10.3 (ESRI, 2015) using the Raster Calculator tool.

\section{Model Validation}

The soil loss estimates were validated using the total sediment observed (Observed SD), obtained with the water discharge and the daily runoff data, according to Beskow et al. (2009). Data of total solids in the water and the respective discharge from 2008 to 2018, obtained from a weather station operated by the Instituto Mineiro de Gestão das Águas (IGAM), were used for this task. This station is located near the Coroado Stream exutory at coordinates $45^{\circ} 53^{\prime} 35^{\prime \prime} \mathrm{W}$ and $21^{\circ} 39^{\prime} 55^{\prime \prime} \mathrm{S}$. There were no data collected by IGAM before 2007 .

Initially, it was built a discharge curve connecting the total transported sediment with the water discharge (Figure 3). Then, the annual transported sediment (Observed SD) was calculated for each year, taking into account the flow $\mathrm{x}$ sediment curve, and the daily runoff dataset for 1988, 1998, 2008, and 2018, obtained from the "Agência Nacional de Águas" (ANA, 2019). The Observed SD was then compared with the soil loss estimate provided by the EPM.

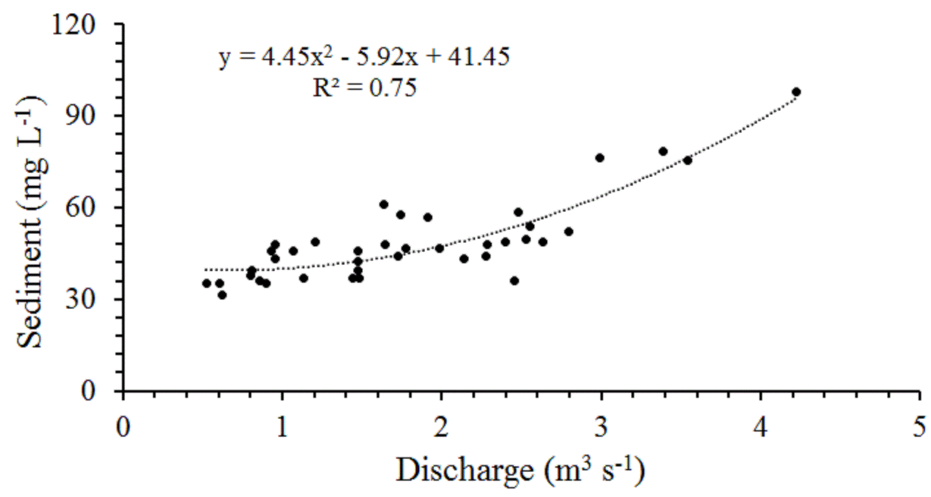

Figure 3. Water discharge curve (sediment transported $\times$ water discharge), of the Coroado Stream Subbasin, Alfenas, south of Minas Gerais State, Brazil.

\section{RESULTS AND DISCUSSION}

\section{Correlation between the observed and the estimated sediment delivery}

The subbasin presented moderate susceptibility to erosion in 1988 and 1998 and low susceptibility in 2008 and 2018. The greatest susceptibility to erosion observed in the years 1988 and 1998, occurred due to the decrease in the vegetation cover of the subbasin caused by the growth of the areas with corn cultivation. Between the analyzed period, the total soil loss $\left(\mathrm{W}_{\mathrm{yr}}\right)$ values ranged from $14,935.81$ to $9,340.80 \mathrm{Mg}$ year $^{-1}$ (Table 5), while between 1988 and 1998, the real soil 
loss $\left(\mathrm{G}_{\mathrm{yr}}\right)$, obtained using the $\mathrm{R}_{\mathrm{u}}$ coefficient, increased by $50.36 \mathrm{Mg}$ year $^{-1}$. The $\mathrm{G}_{\mathrm{yr}}$ increase in the initial years of the study was due to the conversion of pasture to coffee and portions of the forest to eucalyptus (Figure 2). Between 1998 - 2008 and $2008-2018$, there was a reduction in $G_{y r}$ values of
352.49 and 307.72 $\mathrm{Mg}$ year $^{-1}$, respectively. The reduction in $G_{y r}$ possibly contributed to the improvement of water quality in the subbasin, since sediment delivery causes the depreciation of water quality and the silting up of watercourses (POSTHUMUS et al., 2015).

Table 5. Annual erosion, real soil loss, estimated sediment delivery (average soil loss), observed sediment delivery and errors of estimate for the Coroado Stream Subbasin, Alfenas Municipality, south of Minas Gerais State, Brazil.

\begin{tabular}{cccccc}
\hline Year & $\begin{array}{c}\mathrm{W}_{\mathrm{yr}} \\
\left(\mathrm{Mg} \mathrm{year}^{-1}\right)\end{array}$ & $\begin{array}{c}\mathrm{G}_{\mathrm{yr}} \\
\left(\mathrm{Mg} \mathrm{year}^{-1}\right)\end{array}$ & $\begin{array}{c}\text { Estimated SD } \\
\left(\mathrm{Mg} \mathrm{ha}^{-1} \mathrm{year}^{-1}\right)\end{array}$ & $\begin{array}{c}\text { Observed SD } \\
\left(\mathrm{Mg} \mathrm{ha}^{-1} \text { year }^{-1}\right)\end{array}$ & $\begin{array}{c}\text { Error } \\
\left(\mathrm{Mg} \mathrm{ha}^{-1} \text { year }^{-1} \text { and \%) }\right.\end{array}$ \\
\hline 1988 & 14509.07 & 1712.07 & 3.06 & 3.53 & $0.47(13.31)$ \\
1998 & 14935.81 & 1762.43 & 3.15 & 2.64 & $-0.51(19.32)$ \\
2008 & 11948.64 & 1409.94 & 2.52 & 3.14 & $0.62(19.75)$ \\
2018 & 9340.80 & 1102.22 & 1.97 & 3.04 & $1.07(35.20)$ \\
\hline
\end{tabular}

Notes: $\mathrm{W}_{\mathrm{yr}}=$ Annual erosion; $\mathrm{G}_{\mathrm{yr}}=$ real soil loss; $\mathrm{SD}=$ sediment delivery.

Considering the entire study period, the land use and land cover changes that occurred in the subbasin decreased water erosion. Between 1998, the year with the highest $\mathrm{G}_{\mathrm{yr}}$ value, and 2018 , there was a reduction of $660.21 \mathrm{Mg}$ year $^{-1}(-37.46 \%)$ in soil losses. The implementation of coffee and the increase of reforested areas contributed to this result. According to Didoné, Minella and Evrard (2017) an effective scenario for reducing water erosion included the implementation of protected forest areas, which was corroborated with the present study. In addition, as noted, coffee cultivation associated with conservation practices has the potential to reduce soil losses compared to annual crops such as corn (LENSE et al., 2019).

The mean soil loss estimate (Estimated SD) ranged from 3.04 to $3.53 \mathrm{Mg} \mathrm{ha}^{-1}$ year $^{-1}$ with the lowest average in $2018\left(2.64 \mathrm{Mg} \mathrm{ha}^{-1}\right.$ year $\left.^{-1}\right)$. Regarding the Observed SD, it was found a small value in 1988 (Table 5), due to the low precipitation rate in this year (Table 4). Rainfall characteristics are the main factor that affects the Observed SD. According to Mello et al. (2007) and Beskow et al. (2009), rainfall with high erosivity increases Observed SD rates.

The comparison between Observed SD and Estimated SD in 2018 provided an error of $1.07 \mathrm{Mg}$ $\mathrm{ha}^{-1}$ year $^{-1}(35.20 \%)$. For the years of 1988,1998 , and 2008, were found errors of 13.31, 19.32, and $19.75 \%$, respectively. The use of EPM aims to estimate an average annual soil loss (Estimated SD), and on the other hand the Observed SD is obtained from individual rainfall events, for this reason the comparison of these parameters may not coincide and generate high errors (GAVRILOVIC, 1962; EFTHIMIOU; LYKOUDI; KARAVITIS, 2017), as observed in the present study mainly for the year 2018. In addition, the errors may have occurred because the sediment transport monitoring used in the Observed SD calculation did not present data collection before 2007 (due to the high costs involved), resulting in the extrapolation of results to 1988 and 1998, which are outside the collection data period (2007 to 2018). Also, the characterization of indexes from satellite images $\left(X_{a}, \varphi\right)$, presents some uncertainties associated with land use determination (BESKOW et al., 2009).

Soil erosion modeling is, like any other model, a representation of reality rather than reality itself and is therefore prone to uncertainty. Furthermore, modeling, at least on a large scale, should not only focus on accurate prediction of absolute values but rather function as a tool for testing hypotheses of relative differences between management systems and long-term soil loss trends. Both measured and modeled soil erosion rates are relatively well related to each other. However, if they are much higher than soil formation rates, land management cannot be considered sustainable (ALEWELL et al., 2019). Therefore, despite the errors, modeling is efficient in pointing out sites with unsustainable soil management and should be used as a tool to support the adoption of mitigation practices, seeking to minimize the prejudicial impacts of the erosion process as much as possible (VANWALLEGHEM et al., 2017).

\section{Temporal-spatial distribution of soil erosion in the Coroado Stream Subbasin}

The distribution of soil erosion rates revealed the highest soil loss in the steepest areas and in the access roads (Figure 4), due to the exposed soil and heavy machinery traffic. Soil loss values for each year were divided into classes adapted from Beskow et al. (2009) and Avanzi et al. (2013) (Table 6). 

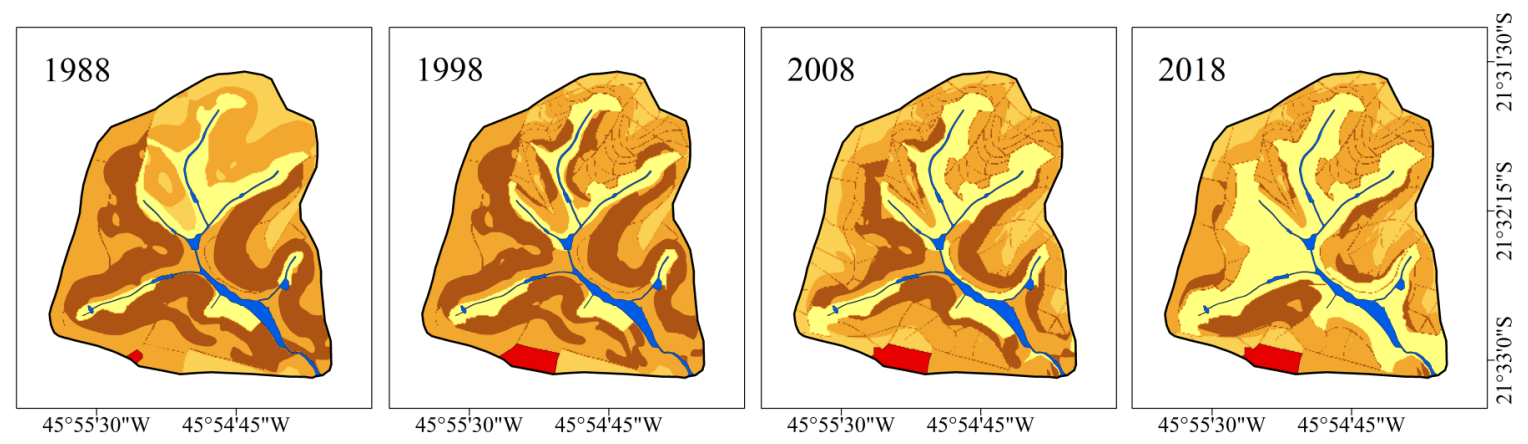

Soil Losses (Mg- ${ }^{-1}$ ha- $^{-1}$ year- $\left.{ }^{-1}\right)$

$\square 0-1 \square 2-4 \square>8=$ Facilities

$\square$ - $-2=4-8 \quad$ Drainage

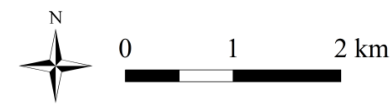

Figure 4. Soil loss classes map of the Coroado Stream Subbasin, Alfenas, south of Minas Gerais State, Brazil, in the years of 1988, 1998, 2008 e 2018.

Table 6. Qualitative classes of soil loss for the Coroado Stream Subbasin, Alfenas Municipality, south of Minas Gerais State, Brazil.

\begin{tabular}{cccccc}
\hline Soil loss & \multicolumn{4}{c}{ Area (\%) } & \multirow{2}{*}{ Soil loss class qualitatively } \\
\cline { 2 - 5 }$\left(\mathrm{Mg} \mathrm{ha}^{-1}\right.$ year $\left.^{-1}\right)$ & 1988 & 1998 & 2008 & 2018 & Very Slight \\
\hline $0-1$ & 16.36 & 16.8 & 23.32 & 39.69 & Slight \\
$1-2$ & 10.30 & 6.96 & 15.14 & 10.38 & Slight to Moderate \\
$2-4$ & 40.43 & 44.16 & 40.90 & 37.88 & Moderate \\
$4-8$ & 32.91 & 32.06 & 20.56 & 11.96 & High \\
\hline 8 & 0.00 & 0.02 & 0.08 & 0.09 & \\
\hline
\end{tabular}

Notes: Soil loss class qualitatively adapted from Beskow et al. (2009) and Avanzi et al. (2013).

The results indicate that, over the years, there was an increase in areas classified with Very Slight and Slight erosion rates and reduction in areas with soil loss classified as Slight to Moderate and Moderate (Table 6). These results can be explained by the increase of 72.6 ha to 193.9 ha $(167.0 \%)$ in forested areas from 1988 to 2018. Furthermore, coffee cultivation with the adoption of conservation practices (level planting, weed management between the lines) and the reduction of corn cultivated under conventional tillage, contributed to the positive result (Table 1). Between 1988 and 1998, there was a decrease in areas with soil loss classified as Slight and an increase of areas with Slight to Moderate erosion. This result was affected by the expansion of deforestation and the conversion of the pasture to temporary crops. However, these areas were recovered in the following years. In 1988, no site was identified by the model as presenting a High level of erosion, remaining almost the same in 1998, when less than $1 \%$ of the watershed shown this level of degradation. Nevertheless, there was an increase of access roads between 1998 and 2018, which could have caused soil exposition, and combined with the steepest relief, led to a more concerning scenario, where there was also the development of new sites with a high level of erosion.
In general, soil loss decrease over the 30 years of study, mainly due to the increase in reforestation areas, driven by environmental legislation in the Atlantic Forest biome, which requires the allocation of at least $20 \%$ of rural property to conservation areas (BRASIL, 2012). Hence, the appropriate use of the public policies could influence the environmental system as a whole, and still contribute to soil preservation, reducing the risk of soil erosion (DEVÁTÝ et al., 2019).

The correct use of land in the steepest areas also contributed to mitigate soil losses, once these areas are the most affected by the erosive process. Between 1988 and 2008, the vast majority of areas with declivity above $20 \%$ (200 ha), which were occupied with corn cultivated under conventional tillage were replaced by coffee and reforestation crops (Figure 5), which resulted in a reduction of $146.50 \mathrm{Mg}$ year $^{-1}$ in soil losses. Temporary crops grown in the steepest areas can make the soil more susceptible to runoff, and therefore these areas should be a priority for the adoption of erosion mitigation measures and for planning the appropriate land use in order to reduce the erosion process (BESKOW et al., 2009; CHEN et al., 2019; LENSE et al., 2020). 


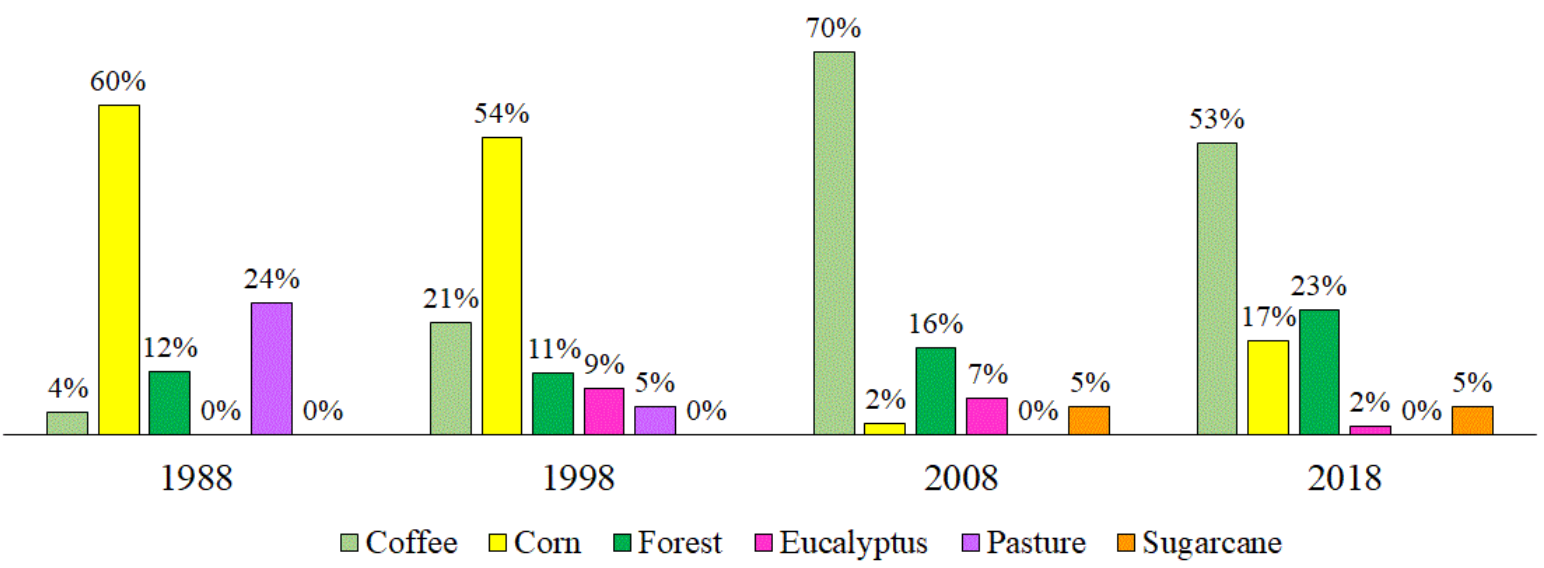

Figure 5. Percentage of land occupied by forest and agricultural crops in areas with declivities above $20 \%$ in the Coroado Stream Subbasin, Alfenas, south of Minas Gerais State, Brazil, in the years 1988, 1998, 2008 and 2018.

The study pointed out that, despite the soil loss reduction, high erosion rates still occur in the study area, mainly on access roads and corn cultivation (Figure 4 - 2018). Therefore, to ensure the long-term sustainability of the production system, soil conservation practices should be expanded, even to site with very slight erosion. The reduction of runoff and sediment loss in the access roads can be achieved by the implementation of retention basins. In areas with corn and sugarcane cultivation, the adoption of a continuous no-till system and the building of the terraces to leveling the land can mitigate the erosion problem (DIDONÉ; MINELLA; EVRARD, 2017).

Studies applying the EPM on a temporal scale in tropical regions were not detected. However, our results demonstrated what this model presented efficient results being a useful tool for understanding the temporal and spatial dynamics of the erosive process and for the sustainable land use planning. Moreover, the model is advantageous for areas with little available information, which is common in much of the Brazilian territory.

\section{CONCLUSION}

In the Coroado Stream Subbasin the conversion of pasture and corn cultivation in coffee crops with the adoption of conservationist practices and especially the expansion of reforestation contributed to the reduction of the erosive process intensity, supporting the hypothesis tested.

The reforestation in the Coroado Stream Subbasin was driven by the need to comply with the Brazilian Forest Code, thus emphasizing the importance of public policies for environmental conservation.

\section{ACKNOWLEDGMENTS}

The authors thank the Fundação de Amparo à Pesquisa do Estado de Minas Gerais (FAPEMIG) for the scholarship offered to the first author. The group Ipanema Agrícola S. A. for funding the research and conceding the study area.

This study was financed in part by the Coordenação de Aperfeiçoamento de Pessoal de Nível Superior - Brasil (CAPES) - Finance Code 001 .

\section{REFERENCES}

ALEWELL, C. et al. Using the USLE: Chances, challenges and limitations of soil erosion modelling. International Soil and Water Conservation Research, 7: 203-225, 2019.

ALVARES, C. A. et al. Köppen's climate classification map for Brazil. Meteorologische Zeitschrift, 22: 711-728, 2013.

AGÊNCIA NACIONAL DE ÁGUAS - ANA. Sistema Nacional de Informações sobre Recursos Hídricos (SNIRH). 2019. Available in: <https:// www.snirh.gov.br/hidroweb/>. Access in: $10 \mathrm{dec}$. 2019.

AVANZI, J. C. et al. Spatial distribution of water erosion risk in a watershed with eucalyptus and Atlantic Forest. Ciência e Agrotecnologia, 37: 427434, 2013.

BESKOW, S. et al. Soil erosion prediction in the Grande River Basin, Brazil using distributed modeling. Catena, 79: 49-59, 2009. 
BRASIL. Congresso Federal. Código Florestal Brasileiro - Lei $n^{0}$ 12.651. 2012. Available in: $<$ http://www.planalto.gov.br/ccivil_03/_Ato20112014/2012/Lei/L12651.htm>. Access in: 12 dec. 2019.

CHEN, Z. et al. Land-use change from arable lands to orchards reduced soil erosion and increased nutrient loss in a small catchment. Science of The Total Environment, 648: 1097-1104, 2019.

DEVÁTÝ, J. et al. Effects of historical land use and land pattern changes on soil erosion - Case studies from Lower Austria and Central Bohemia. Land Use Policy, 82: 674-685, 2019.

DIAS, L. C. P. et al. Patterns of land use, extensification, and intensification of Brazilian agriculture. Global Change Biology, 22: 2887-2903, 2016.

DIDONÉ, E. J.; MINELlA, J. P. G.; EVRARD, O. Measuring and modelling soil erosion and sediment yields in a large cultivated catchment under no-till of Southern Brazil. Soil and Tillage Research, 174: 24 $-33,2017$.

EFTHIMIOU, N.; LYKOUDI, E.; KARAVITIS, C. Comparative analysis of sediment yield estimations using different empirical soil erosion models. Hydrological Sciences Journal, 62: 2674-2694, 2017.

ENVIRONMENTAL SYSTEMS RESEARCH INSTITUTE - ESRI. ARCGIS Professional GIS for the desktop version 10.3. Redlands, EUA: Software, 2015. Available in: <https:// desktop.arcgis.com/en/arcmap/10.3/get-started/quick -start-guides/arcgis-desktop-quick-start-42 guide.htm>. Access in: 10 dec. 2019.

FOOD AND AGRICULTURE ORGANIZATION OF THE UNITED NATIONS - FAO. Voluntary Guidelines for sustainable soil management food and agriculture organization of the united nations. Rome: FAO, 2017. Available in: <http:// www.fao.org/3/a-bl813e.pdfhttp://www.fao.org/3/ab1813e.pdf>. Access in: 18 dec. 2019.

GAVRILOVIC, S. A method for estimating the average annual quantity of sediments according to the potency of erosion. Bulletin of the Faculty of Forestry, 26: 151-168, 1962.

INSTITUTO BRASILEIRO DE GEOGRAFIA E ESTATÍSTICA - IBGE. Carta Topográfica do Município de Alfenas (FOLHA SF 23-1-1-3), 1970. Alfenas, 1970.
INSTITUTO NACIONAL DE METEOROLOGIA INMET. Estações pluviométricas convencionais. Ministério da Agricultura, Pecuária e Abastecimento (MAPA), 2019. Available in: <http:// www.inmet.gov.br/portal/index.php?r=bdmep/ bdmep >. Access in: 18 dec. 2019.

INSTITUTO NACIONAL DE PESQUISAS ESPACIAIS - INPE. Divisão de Geração de Imagens (DIDGI). Ministério da Ciência, Tecnologia, Inovações e Comunicações, 2019. Available in: <http://www.dgi.inpe.br/catalogo/>. Access in: 02 dec. 2019.

LENSE, G. H. E. et al. Estimates of soil losses by the erosion potential method in tropical latosols. Ciência e Agrotecnologia, 43: e012719, 2019.

LENSE, G. H. E. et al. Simulating the effect of permanent preservation areas on soil erosion rates. Cerne, 26: 193-201, 2020

MANZATTO, C. V.; FREITAS JUNIOR, E.; PERES, J. R. R. Uso agrícola dos solos brasileiros. 1 ed. Rio de Janeiro, RJ: Embrapa Solos, 2002. 184 $\mathrm{p}$

MELLO, C. R. et al. Erosividade mensal e anual da chuva no Estado de Minas Gerais. Pesquisa Agropecuária Brasileira, 42: 537-545, 2007.

OUYANG, W. et al. Soil erosion dynamics response to landscape pattern. Science of The Total Environment, 408: 1358-1366, 2010.

OUYANG, W. et al. Combined impacts of land use and soil property changes on soil erosion in a mollisol area under long-term agricultural development. Science of The Total Environment, 613: 798-809, 2018.

POSTHUMUS, H. et al. Costs and benefits of erosion control measures in the UK. Soil Use and Management, 31: 16-33, 2015.

SIMÕES, J. C.; PELEGRINI, D. F. Diagnóstico da cafeicultura mineira: regiões tradicionais - Sul/ Sudoeste de Minas, Zona da Mata, Triângulo Mineiro/Alto Paranaíba. 1. ed. Belo Horizonte, MG: EPAMIG, 2010. 56 p.

SOIL SURVEY STAFF. Keys to Soil Taxonomy, 12th ed. Washington: USDA-Natural Resources Conservation Service, 2014.

VANWALLEGHEM, T. et al. Impact of historical land use and soil management change on soil erosion and agricultural sustainability during the Anthropocene. Anthropocene, 17: 13-29, 2017. 